\title{
De Platão a Rubem Alves: Eros na educação contemporânea
}

\section{Luiza de Freitas Nunes ${ }^{1}$}

\section{Resumo}

O amor é um tema presente nas mais diversas obras platônicas, das quais constitui grande referência: Fedro, Lisis, República e, o mais importante e especialmente dedicado ao tema, Banquete. Para Platão, o amor é a base da educação. O mesmo dirá Rubem Alves na contemporaneidade. Interessa-nos, então, entender esse amor platônico que leva o nome de Eros - a partir, sobretudo, das obras Banquete e Fedro - e apontar, seguindo o caminho da pedagogia rubemiana, sua importância como instrumento e base para a educação contemporânea.

Palavras-chave: Platão; Eros; Educação.

\begin{abstract}
Love is a recurring theme of Platonic works, of which the following are worth of mention: Phaedrus, Lysis, Republic and the most important one, especially dedicated to the issue, Symposium. For Plato, love is the base of education, as well as Rubem Alves says in contemporaneity. Therefore we intend to understand platonic love, that is called Eros, from Symposium and Phaedrus mainly. Also, we aim at pointing its importance as means and base to contemporary education, following the path of Alves's pedagogy.
\end{abstract}

Key-words: Plato; Eros; Education.

\footnotetext{
${ }^{1}$ Licenciada em Filosofia e bacharela em Ciências e Humanidades pela Universidade Federal
} do $\mathrm{ABC}(\mathrm{UFABC})$. 
Introdução

$$
\begin{aligned}
& \text { O sexo e o cérebro não são músculos, nem podem ser. Disso } \\
& \text { decorrem várias consequências importantes, das quais esta } \\
& \text { não é a menor: não amamos o que queremos, mas o que } \\
& \text { desejamos, mas o que amamos e que não escolhemos. } \\
& \text { Comte-Sponville (2009, p.24I) }
\end{aligned}
$$

ideia presente na epígrafe de André Comte-Sponville que abre
este texto é também bastante difundida em diversas obras de
Rubem Alves acerca da educação. Em seu texto "Do desejo de aprender" (2012a, p.82-83), por exemplo, o autor nos diz que "A gente aprende aquilo que deseja aprender. É o desejo que desperta em nós a inteligência". Já em "Pensar" (2014, p.61) nos deparamos com uma importante orientação sobre o ato de ensinar: "A tarefa primordial do professor: seduzir o aluno para que ele deseje e, desejando, aprenda". No limite, o que ambos os autores dizem é que amar não é uma questão de escolha, isto é, de querer, mas antes de desejar. Não desejo porque quero; quero porque desejo. Há aí uma distinção fundamental: para aquilo que queremos temos a capacidade de escolha; para aquilo que desejamos, desejamos sem que haja controle sobre este desejo. Ora, o desejo é uma coisa que nasce sem que dele tenhamos controle imediato.

Ao contrário de Comte-Sponville, Alves não usa a palavra amor nos trechos referidos. Entretanto, dissemos que ambos falam de amor. Isto porque a pedagogia de Rubem Alves é uma espécie de "Pedagogia do Amor", ou seja, nela o amor não é algo separável da educação, mas a ela atrelado. Esta pedagogia, guardada a distância, se aproxima muito daquela que, já no século V a.C., Platão difundia, ainda que com outros nomes. Não é difícil, no entanto, notar a influência do filósofo no educar ao estilo de Rubem Alves. Alves parte do desejo para falar sobre ensino-aprendizagem e desejo é, não coincidentemente, a base da educação platônica. E se Rubem Alves por muitas vezes apresenta metáforas entre o ato de ensinar/aprender e o ato de “transar", não obstante, esta é uma das facetas do Eros platônico, amor erótico 
que se refere, por um lado, ao corpo, e, por outro, e mais importante, à alma. É, sobretudo, a esta segunda face do Eros platônico que pretendemos dar atenção. É ela que nos interessa enquanto um importante instrumento de ensino-aprendizagem para a educação contemporânea.

\section{Eros platônico}

O Banquete é um diálogo platônico voltado especificamente ao exame do que é o amor Eros. O enredo consiste da narração de Apolodoro sobre a história que lhe conta Aristodemo acerca do banquete dado por Agatão. É um cenário no qual alguns amigos se reúnem na casa de Agatão no intuito de comemorar seu sucesso em um concurso de tragédia ocorrido dias antes. Sendo um simpósio, todos comem e bebem, mas neste banquete, sobretudo, fala-se. O tema escolhido a ser objeto e diretriz dos discursos é Eros. A ideia de se fazer um elogio de Eros em tal ocasião é dada por Erixímaco a partir de um comentário de Fedro ${ }^{2}$ sobre o descaso dos poetas para com esta divindade:

Minha ideia é de todos os presentes fazerem o elogio de Eros, por ordem, da esquerda para a direita, da maneira mais bela possível, a principiar por Fedro, não apenas por estar no primeiro lugar na mesa, como por haver partido dele a sugestão. (Cf. Platão, Banquete, 177d.)

A ideia, ao fazer os discursos, não é, no entanto, promover confissões, mas buscar uma definição de Eros. "Não que se façam confidências, ou quase não. [...] É mais uma definição que eles buscam, cada um querendo captar a essência do amor fazendo seu elogio, ou louvá-lo dizendo o que ele é" (COMTE-SPONVILLE, 2009, p.246). Entretanto, grande parte dos discursos carregará, fundamentalmente, ilusões sobre o amor $^{3}$. De forma que os dois

\footnotetext{
2 "Não é absurdo", Erixímaco repete sempre, "que para todos os deuses os poetas tenham composto hinos e peãs, e com relação a Eros, divindade tão grande e gloriosa, entre tantos poetas como já tivemos, não houve um só que fizesse o seu panegírico?”. (Cf. Platão, Banquete, 177a-b).

${ }^{3}$ Segundo C. D. C. Reeve (2011, p.278) sobre o assunto: "A história de todos os outros membros do banquete são também histórias de seus amores particulares escamoteadas como histórias de amor, histórias sobre o que eles acham belo escamoteadas como histórias sobre o que é belo. [...] Em um modo de que estes homens não estão conscientes, mas que Platão
} 
discursos que realmente nos interessam são o de Aristófanes e, inevitavelmente, o de Sócrates que, recorrendo às conversas que tivera com Diotima de Mantinéia ${ }^{4}$, profere o discurso supostamente verdadeiro acerca de Eros. O que acontece até o momento destes dois discursos é, basicamente, a exposição de Fedro sobre Eros ser o deus mais antigo e sobre o amante ser mais divino do que o amado; Pausânias distinguindo o amor vulgar (ou Pandêmio) do amor celeste (ou Urâneo); Erixímaco expondo o poder universal do amor e também o dividindo em dois: saúde e doença ${ }^{5}$; e, por fim, Agatão (discursando entre Aristófanes e Sócrates) defendendo que Eros não é o deus mais antigo, mas sim o mais jovem. Quando esses homens discorrem sobre o amor, falam com total sinceridade, uma vez que contam sobre suas histórias particulares, expressam aquilo em que acreditam. Entretanto, é preciso que se confronte estes discursos uns com os outros, para que os argumentos sejam analisados no intuito de saber se têm ou não consistência. $\mathrm{O}$ amor nos discursos proferidos no Banquete parece, assim, dividir-se em dois desejos: um primeiro referente ao desejo pelo próprio amor (corporal ou o de alma) e um segundo referente ao desejo racional de contar (e viver) uma história de amor coerente com o que sobre o amor se pensa (REEVE, 2011). Deste modo, os discursos expressos por aqueles homens, uma vez tomados por estes desejos, acabam por não apresentar uma definição clara de Eros.

Não nos enganemos, pois Aristófanes também proferirá um discurso ilusório. Talvez o mais ilusório de acordo com a visão platônica. Se recorremos ao discurso de Aristófanes junto ao de Sócrates e os consideramos

conhece, suas histórias de amor são elas próprias manifestações de seus amores e das inversões ou perversões nelas expressas". Ainda assim, embora a maioria dos discursos do Banquete sejam apenas ilusões, nem por isso, dirá Reeve, deixam de ser parte essencial da verdade sobre o amor.

${ }^{4}$ Diotima de Mantinéia é uma sacerdotisa e filósofa grega que no Banquete é mencionada por ter desempenhado o importante papel de ensinar a Sócrates a natureza do amor e, em consequência, a arte de amor, já que este não é exatamente hábil nesta arte, embora domine algumas de suas tarefas. Esta natureza que Diotima ensina a Sócrates será a base da teoria platônica sobre o amor. Sendo Platão a única fonte sobre ela, não é possível dizer se é apenas uma personagem fictícia ou se alguém que de fato existiu.

${ }^{5}$ Cabe dizer que Erixímaco faz esta distinção porque é um médico, e sendo médico fala do amor do ponto de vista da medicina. Chega até mesmo a definir a medicina como "a ciência dos fenômenos amorosos do corpo com relação à repleção e à vacuidade, sendo o médico mais hábil o que sabe distinguir nessas manifestações entre o bom e o mau amor" (Cf. Platão, Banquete, 187d-e). 
como sendo os dois mais interessantes ao nosso assunto, é unicamente porque aquele falará do amor tal como frequente e comumente o definimos, enquanto este falará sobre o amor no que seria a sua suposta verdade, isto é, aquilo que, aparentemente, seria sua identidade:

Aristófanes nos diz exatamente, sobre o amor, o que todos gostaríamos de acreditar (é o amor como sonhamos, o amor saciado e saciante: a paixão feliz); ao passo que Sócrates diz o amor como ele é, destinado à carência, à incompletude, à miséria [...]. (COMTE-SPONVILLE, 2009, p.247).

Assim, a narrativa de Aristófanes tem por objetivo explicar o poder de Eros. Partindo da explicação da natureza humana e das modificações pelas quais ela passou, o orador inicia seu discurso dizendo que outrora existiam três sexos: feminino (originado da terra), masculino (oriundo do sol) e andrógino (derivado da lua). Além disso, os seres humanos primitivos eram de uma configuração diferente da atual: tinham corpos redondos, possuíam quatro mãos e quatro pernas, quatro orelhas e dois órgãos genitais, dois rostos iguais sobre um único pescoço e em uma só cabeça, etc. Os corpos do sexo masculino carregavam um duplo corpo masculino, igualmente os corpos do sexo feminino carregavam um duplo corpo feminino. Já os corpos andrógenos constituíam-se de uma parte feminina e outra masculina. Diz-nos Aristófanes que os andróginos foram cortados ao meio, como uma punição por tentarem combater os deuses. Este corte deu origem a homens e mulheres diferentes daqueles primitivos. Nossos ancestrais eram duplos, mas possuíam uma unidade e completude. A partir do momento em que tiveram seus corpos cortados ao meio, geraram indivíduos incompletos e sem unidade. E cada um é obrigado a procurar a sua metade. Dado este quadro, o amor, segundo Aristófanes, é a saudade do todo, ou seja, da unidade. Também o empenho de reestabelecer esta unidade é entendido como sendo o amor. Esta definição é a de um amor exclusivo, pois que cada um tem uma metade. É a ideia comum que temos de amor: algo que é completude, que é exclusivo e eterno, posto 
que, tendo encontrado sua metade e reestabelecido sua unidade, o individuo estará satisfeito por toda a vida.

Sócrates emite um discurso contrário ao falatório de completude e unidade feito por Aristófanes. O filósofo, recuperando as afirmações do discurso a ele feito por Diotima de Mantinéia, nos diz que o objeto do desejo e do amor é aquilo do que se carece. Deste modo, o amor é, primeiro, amor de certas coisas e, depois, de algo de que sentimos falta. $\mathrm{O}$ amor é desprovido de beleza e igualmente desprovido daquilo que é bom. O mais importante, contudo, é que o que não é belo não é necessariamente feio, como o que não é bom não é impreterivelmente mau. Deste modo, Eros não é belo nem feio, tampouco bom ou mau. E por não participar das coisas boas nem belas, Eros não pode ser um deus. De forma alguma, porém, é mortal. Eros, portanto, é algo de intermediário entre os deuses e os mortais - precisamente um daimon. A função deste amor é "interpretar e levar para os deuses o que vai dos homens, e para os homens o que vem dos deuses: de um lado, preces e sacrifícios; do outro, ordens e as remunerações dos sacrifícios" (PLATÃO, Banquete, 203a). É por meio de Eros que os deuses entram em contato com os homens em estado de vigília ou no sono. Eros, além disso, é fillho de Poros - personificação da Riqueza, segundo a mitologia grega - e da Pobreza. Consequentemente, nunca é rico nem pobre: o que adquire hoje perde amanhã. Mas uma vez que é filho da Pobreza, é companheiro eterno da indigência ${ }^{6}$. Não é delicado nem belo. Ao contrário, é áspero, esquálido e sem calçado nem domicílio certo. Sendo filho de Poros, é bravo, audaz, expedito, amigo da sabedoria, filósofo em tempo integral, feiticeiro temível, mágico e sofista. Eros, embora não possua beleza, é amante do belo e, portanto, amante da sabedoria (aquilo que há de mais belo).

Segundo o discurso de Sócrates, o amor não é completude, sequer unidade. E só será, em suma, a procura da metade ou do todo se essa metade e se esse todo forem bons. Amor é, pois, o desejo de possuir sempre o bem. Ademais, visto que o amor ama o que é belo, "[a]mar é gerar na beleza, ou

\footnotetext{
${ }^{6}$ Aqui o sentido dado à palavra indigência não se refere à ideia contemporânea de extrema pobreza, mas sim ao sentido de carência, de falta ou necessidade de algo.
} 
segundo o corpo, ou segundo o espírito" (PLATÃO, Banquete, 206c). Uma vez que procriar e gerar no belo é o ato de participar da eternidade, o amor é o anseio da imortalidade. Ora, a perpetuidade do que é mortal se dá apenas pelo ato de retirar-se o que envelhece e deixar em seu lugar algo mais novo, como se fosse o mesmo.

Dois são, pois, os tipos de forças fecundantes: a que reside no corpo e busca gerar filhos; e a que reside na alma e busca gerar a sabedoria e as demais virtudes. É, por conseguinte, esta segunda força que nos interessa.

O amor, enquanto desejo do belo, leva ao amor à sabedoria, pois a busca pelo belo engendra um processo, como descrito no Banquete, que parte do mundo sensível para o mundo inteligível. Neste decurso, primeiro ama-se um único corpo, depois todos os corpos - posto que a beleza não sendo do âmbito do sensível não pode estar apenas em um só corpo. Dos corpos passa-se, então, a amar as belas almas e tão logo os ofícios, as leis e as ciências.

Durante o andamento da busca pelo belo produzem-se belos discursos, e essa produção, pelo amor à sabedoria, leva ao mundo das Ideias. Estes discursos que tem o poder de levar os indivíduos ao mundo das Ideias não são, porém, de qualquer tipo. Somente aqueles que seguem o método dialético tem tal capacidade. A dialética, segundo o Fedro, é o caminho para o mundo inteligível, pois pela contradição e divisão dos opostos chega-se à verdade, núcleo comum, indivisível e no qual não há incoerência.

O método dialético socrático-platônico tem duas vias: uma negativa (que se refere ao recurso da refutação, por meio do qual liberta-se o outro do falso saber) e outra positiva (relativo à maiêutica, isto é, o procedimento pelo qual traz-se à luz uma verdade). Esta segunda via do método dialético, uma vez que pressupõe que todo conhecimento está na alma, sendo, portanto, lembrança, é também a base para a Teoria da Reminiscência apresentada no dialogo Fedro: a alma é imortal e de natureza divina, por esse motivo ela preexiste aos corpos. Nesta preexistência, participa do cortejo dos deuses, fazendo parte do exército de um dos doze deuses existentes. Na tentativa de explicar o que é a alma, Sócrates faz uma analogia com uma biga composta por um condutor, um cavalo de boa conduta e um cavalo de má conduta. 
Assim, quando participa do cortejo dos deuses - cujas bigas possuem apenas cavalos de boa conduta - e estes rumam ao topo do céu a fim de comtemplar o mundo das Ideias, as almas cujos condutores não conseguem controlar o cavalo de má conduta começam a cair, pois o cavalo de má conduta é pesado e puxa a biga para a Terra. Apenas as almas que seguem a Zeus (não por acaso aquelas que serão as almas dos filósofos) conseguem chegar ao topo do céu e contemplar, em alguma medida, as Ideias. No entanto, ainda que as almas do cortejo de Zeus sejam aquelas que em maior grau contemplem o mundo Inteligível, em alguma medida todas as outras almas, porém, já o observaram e, diante disso, tiveram acesso a alguma verdade. E todas as almas, em absoluto, já apreciaram em algum grau o Belo ${ }^{7}$. Ora, as almas quando caem, isto é, quando se direcionam para a Terra, acabam por perder suas asas. O amor sendo o estado de contemplação da beleza no mundo sensível - para além de ser o desejo do belo - gera a reminiscência do verdadeiro Belo, irrigando as passagens das penas das asas da alma e fazendo com que elas cresçam.

Ora, o crescimento das asas, na teoria platônica, é importante exatamente para que a alma possa alcançar o mundo Inteligível. Em vista disso, podemos dizer que o amor é o que dá força às asas para esse propósito.

Na relação ensino-aprendizagem, o ato de despertar o desejo é também, em consequência, um modo de despertar a reminiscência do belo, ajudando a alma em sua elevação para o Belo em si. Assim, é possível notar o quanto o belo está intimamente relacionado com o amor (seja ele Urânio ou Pandêmio), porque o amor não só tem o poder de criar imagens do belo como também de levar ao Belo em si. A beleza que capturamos no mundo material nos faz ter uma reminiscência da verdadeira beleza. Daí a educação, nesta relação, ser uma força fecundante que gera a sabedoria através do amor, isto é, primeiro do desejo do belo e em seguida de todas as outras Ideias.

${ }^{7} \mathrm{O}$ Belo em si é aquilo que mais resplandece no mundo das Ideias, por isto é o elemento mais facilmente visto pelas almas. 


\section{Amor, Educação e Sociedade Civil Ateniense}

A sociedade ateniense ensinava a cidadania através da paiderastia, uma relação social regulamentada que se refere à ligação entre um rapaz jovem e um homem mais velho com o objetivo de que o rapaz jovem aprenda a virtude para se tornar um cidadão.

Segundo Luc Brisson e Jean-François Pradeau (2010, p.72-73):

A virtude é a excelência na função própria. Já que cada coisa, ou seja, cada objeto assim como cada ser vivo tem uma ou mais funções, a virtude consiste no fato de exercer perfeitamente essa função. Assim, a virtude de uma tesoura será cortar, a de um olho ver e as do homem saber, ser corajoso e conseguir dominar seus desejos.

A ideologia da paiderastia ateniense diz que o amor se divide em bom e mau. O bom amor é o Urânio, que tem a alma como objeto, e inspirar a virtude no rapaz jovem é seu objetivo. Já o mau amor se refere ao Pandêmio, que tem o corpo como objeto e o prazer sexual do amante, isto é, do homem mais velho, como objetivo. $\mathrm{O}$ amor Pandêmio por vezes se mascara como amor Urânio para preservar a ilusão de que participar de um amor desse tipo é compatível com a condição de um futuro cidadão. Entretanto, do jovem rapaz não se espera que tenha pelo homem mais velho um amor sensual. Desta forma, o prazer sexual é apresentado como uma servidão em vista da virtude, de modo que a relação sexual, focada no corpo do homem mais velho, é disfarçada por uma relação mais respeitável.

Segundo Platão, na relação amorosa com vistas à sabedoria, o amante (rapaz jovem) vê no amado (o homem mais velho) a beleza e logo é tomado pelo amor (Eros) porque tem a reminiscência do Belo, fazendo com que suas asas cresçam e desejando, assim, sempre estar em companhia do amado. O amado também passa a ver beleza no amante, transformando ambos em amante. É a relação, quando tomados por este amor, que faz contemplar a beleza, ter a reminiscência do Belo e, assim, produzir aqueles belos discursos através do método dialético. 
Para Reeve (2011, p.276), “As teses de Platão sobre o amor são uma meditação sobre Sócrates e sobre o poder que suas discussões filosóficas possuem de arrebatar, obcecar e educar". As obras platônicas que tratam do amor de fato são sempre um dialogo em que Sócrates se vale do método dialético para buscar responder uma questão inicial. Assim, em todas as obras revela-se o ensino da arte segundo a qual é possível alcançar a sabedoria. Em Lísis, a relação entre amor e sabedoria é tão explorada quanto no Banquete, embora o viés agora seja a amizade. Quando busca descobrir o fundamento e a natureza da amizade, as lições de Sócrates sobre o amor são, na realidade, lições "elênticas", isto é, lições sobre como manter uma discussão, sobre como perguntar e responder questões. Em última instância, a arte do amor consiste em saber falar com o amado. Ainda segundo Reeve (2011, p.27):

A conexão que redunda em uma identificação, entre a arte da discussão e a arte de amar rapazes explorada no Lísis nos permite ver por que as explorações do próprio Platão sobre o amor inevitavelmente envolvem também uma exploração da discussão: fala sobre o amor em Lísis, elaboração de discursos e drama simpósicos no Banquete, oratória e retórica em Fedro. Amar corretamente os rapazes consiste, afinal, em ou pelo em partes (sic) - simplesmente saber como falar com eles, como persuadi-los a amá-lo em troca.

O amor e a educação são, então, dois elementos correlacionados nas obras platônicas, bem como nas relações da paiderastia grega, conforme descrita por Platão. E se amor e educação estão correlacionados, o desejo está conjuntamente presente neste vínculo, dada a noção de Eros. Não pode haver educação sem amor, porque não pode haver educação sem desejo. Enquanto desejo do belo, desejo e amor são uma só e mesma coisa.

Embora Platão não tenha de fato escrito uma pedagogia, sua definição de Eros e a relação que faz entre amor e discurso, nos dá importantes lições pedagógicas. Talvez a maior delas seja a de que só pode haver uma relação de ensino-aprendizagem efetiva se o ensino puder ser belo aos olhos de quem 
está em posição de aprendizagem e igualmente a quem ensina (ora, não é por isso que o amado se torna amante e vice-versa?).

\section{A pedagogia de Alves e suas semelhanças com Platão}

Rubem Alves não escreveu livros de teoria pedagógica. Não encontraremos em seu nome obras indicando práticas e métodos para o processo de ensinoaprendizagem. Todavia, dentre as suas numerosas publicações, encontram-se muitos volumes dedicados especificamente à educação e outros tantos que, embora não a tenham como foco, abrigam diversas crônicas sobre o tema. Se dizemos que existe uma pedagogia relacionada a Rubem Alves é porque ao pensar e escrever sobre educação, o autor não só nos relata o que a seu ver deveriam ser os princípios da educação como, ainda que sem intenção, dános importantes diretrizes.

"Primeiro amar, depois conhecer. Conhecer para poder amar. Porque, se se ama, os olhos e os pensamentos envolvem o objeto, como se fossem mãos, para colhê-lo" (ALVES, 2013a, p.104). Nos escritos de Rubem Alves, educação sempre vem associada ao amor, este elemento tão impopular entre pedagogos, educadores e professores que se perguntam por coisas mais práticas e menos abstratas. Diz-nos Rubem Alves (2013b, p.235) que:

\footnotetext{
A palavra amor se tornou maldita entre os educadores. Envergonhamse de que a educação seja coisa do amor - piegas. Mas o amor - Platão, Nietzsche e Freud o sabiam - nada tem de piegas. O amor marca o impreciso e forte círculo de prazer que liga o corpo aos objetos. Sem o amor, tudo nos seria diferente - indigno de ser aprendido, inclusive a ciência. Não teríamos sentido de direção ou não teríamos prioridades.
}

Assim como Platão, Alves foge ao habitual e coloca o amor como sendo a base da educação e do conhecimento (ou do conhecer). Também como aquele, este circunscreve o amor no âmbito do prazer e da alegria. Prazer, o sentimento imediato e passageiro do encontro com o objeto; alegria, o sentimento infindo do contato com o objeto em ato ou virtualidade. Em Variações Sobre o Prazer (2011a, p.84) Rubem Alves nos diz: “[m]inha 
filosofia da educação decorre desse ato de fé, podendo assim ser resumida: o objetivo da educação é aumentar as possibilidades de prazer e alegria. O destino da razão é servo do prazer e da alegria”. Portanto, se o amor é a base da educação e o prazer e a alegria são seu objetivo, então educação também acontece a partir do desejo:

Toda experiência de aprendizagem se inicia com uma experiência afetiva. É a fome que põe em funcionamento o aparelho pensador. Fome é afeto. O pensamento nasce do afeto, nasce da fome. Não confundir afeto com beijinhos e carinhos. Afeto, do latim affecare, quer dizer "ir atrás". O afeto é o movimento da alma na busca do objeto de sua fome. É o eros platônico, a fome que faz a alma voar em busca do fruto sonhado. (ALVES, 2014, p.52)

A influência de Platão nos escritos de Rubem Alves fica clara pelo próprio autor quando este evoca o Eros platônico. Ora, aquele fala em desejo, este fala em fome. Em última instância, são uma só e mesma coisa. Para ambos o desejo e, consequentemente, a não saciedade, é o que mantém o amor. Se o desejo for satisfeito, o pensamento não acontece (ALVES, 2014), porque o desejo só existe enquanto não é saciado daquilo que deseja.

Para além da analogia com a fome, Alves (2011a, 2012b, 2012c, 2013a, 2013b) também utiliza a prática culinária para falar do processo de ensino e, consequentemente, do que se oferece ao aluno para este ensino - e a atitude de um cozinheiro ou uma cozinheira para falar sobre o professorado. Dessa forma, em "Aprendendo das Cozinheiras” (2013a, p.141-146) Alves fala de uma Filosofia Culinária da Educação e pergunta se os professores não poderiam aprender com os cozinheiros, fazer da cozinha a antecâmara das salas de aula e serem, antes de professores, mestres-cucas. No mesmo texto o autor nos diz que a cozinha é o lugar onde se aprende a vida; despreza por isso as cozinhas modernas (rápidas e funcionais) e enaltece a cozinha antiga, "lenta, erótica, lugar onde a química está mais próxima da vida e do prazer", em suas palavras. Os professores deveriam, então, imitar esses especialistas 
da culinária que, utilizando-se da cozinha ao modo antigo não só elaboram bons pratos como ensinam os sabores.

Em “Sobre nabos crus e professores” (2012c, p.136-138), Rubem Alves diz que quando se oferece alhos, cebolas, nabos e tantos outros vegetais crus, sem qualquer tempero, sequer sal, para os alunos de Arte Culinária, isso cria neles uma aversão generalizada pela comida, pois os alunos não conseguem sair da primeira etapa, qual seja, a mastigação desses alimentos. Isto ocorre porque o primeiro prato ofertado não é convidativo, não gera uma alegria de antemão, e o corpo, ao recebê-los, não sorri por antecipação. Com a educação, de modo geral, acontece o mesmo e muitos professores desestimulam seus alunos porque oferecem de pronto um prato que não é cativante, tampouco sedutor.

A primeira pergunta que se deveria fazer a alguém que se candidatasse a uma posição de professor deveria ser: "O senhor gosta dos alunos?". Caso a resposta fosse afirmativa, a segunda pergunta se seguiria: "E qual é o primeiro prato que o senhor lhes serve?”. (ALVES, 2012c, p.138)

Ser professor, portanto, exige, por assim dizer, um tato culinário para que se desperte a fome do aluno, para que aguce seu interesse em entender quais elementos estão presente no prato que lhe foi ofertado, como e porque foi preparado daquela maneira. O professor deveria ser, pois, o cozinheiro que serve o aperitivo para que a criança tenha forme e deseje comer o que se seguirá (ALVES, 2012b).

Rubem Alves fala tanto em culinária e fome quando aborda as temáticas da educação porque ao falar em ensino-aprendizagem, discursa sobre desejo, curiosidade, sobre uma educação mais ligada à vida. E que elemento poderia estar mais ligado à vida que não a alimentação?

A cabeça não pensa aquilo que o coração não pede. Anote isto: conhecimentos que não são nascidos do desejo são como uma maravilhosa cozinha na casa de um homem que sofre de anorexia. 
Homem sem fome: o fogão nunca será aceso. [...] A tarefa do professor é a mesma da cozinheira: antes de dar faca e queijo ao aluno, provocar a fome... Se ele tiver fome, mesmo que não haja queijo, ele acabará por inventar uma maquineta de roubar queijos. (ALVES, 2014, p.55)

Desta forma, a educação e o professor não têm como objetivo ensinar respostas, mas sim despertar o desejo. Não dar o alimento, mas ativar a fome. As respostas e os alimentos existem e estão aí, mas sem o desejo e a fome, de nada servem.

Ora, é o Eros platônico que leva ao conhecimento porque é, antes de tudo, desejo, e só enquanto não estiver saciado daquilo que deseja. Rubem Alves e Platão tratam, guardada a distância, de uma mesma educação: este fala da educação filosófica, que envolve um jovem rapaz e um homem mais velho, aquele aborda a educação como um todo. Ambos, porém, ressaltam a importância do amor erótico no processo de ensino-aprendizagem.

\section{Conclusão}

A pedagogia de Rubem Alves relaciona educação à erótica. Em algumas de suas crônicas, entre elas "Sobre Transar e Ensinar" (2014, p.15-29), e algumas entrevistas $(2011,2013)$, Alves faz analogias entre os órgãos presentes no ato sexual (heterossexual) e os elementos do conhecimento; diz, por exemplo, que a penetração deposita na mulher o sêmen e gera a gravidez, e, transportada a ideia para a educação, temos que o objetivo da penetração é colocar dentro de quem ouve uma semente e, assim, engravidar essa pessoa de uma ideia. Além dessa, Rubem Alves faz outra analogia, entre a inteligência e o pênis: diz que a ereção, ao contrário da flacidez, é o estado do pênis capaz de dar prazer e fecundar; com a inteligência ocorre o mesmo, pois quando excitada, deixa de estar flácida e alcança a ereção. Ora, pênis e inteligência em estado de ereção estão à procura de algo. Em suma, o útero e a mente fazem as vezes do espaço vazio à espera do sêmen e da semente, lugar da criação, onde o novo será gerado. 
É evidente que Alves, com suas propostas e analogias, faz um retorno ao Eros platônico. Eros aparece, como visto, como uma espécie de amizade pedagógica porque nasce na relação entre o homem e o jovem, isto é, entre o mestre e seu discípulo ou entre aquele que conhece e aquele que busca conhecimento. Esse desejo cada vez maior de estar na companhia do outro pode também despertar o desejo de tocá-lo sexualmente, ou seja, de consumar o ato sexual. Este desejo, porém, e como aponta Platão em A República, deve ser superado e redirecionado para o âmbito intelectual.

Se nos concentrarmos no amor intelectual, veremos que Eros nos aponta um importante elemento erótico da educação: a sedução, o desejo. É disso que, em última instância, fala Rubem Alves quando compara educação ao ato sexual. Não é preciso, todavia, ir tão longe quanto o pensador e fazer analogias entre os órgãos envolvidos no ato sexual heteronormativo e os elementos envolvidos na educação, isto é, pênis e inteligência, sêmen e semente, etc. Contrariamente a Alves, defendemos que o desejo já é a semente que plantamos e é ele que faz com que a inteligência e o conhecimento sejam estimulados. Ora, acreditamos que o desejo vem primeiro, como sendo aquilo que excita. Não seria, propriamente, a penetração o que deposita uma semente e faz crescer em alguém uma ideia, mas a sedução, a atração e o encanto que o objeto gera antes mesmo de ser conhecido. Todo esse fascínio se dá na apresentação do objeto, no quanto ele nos interessa e/ou nos parece interessante. Essa é a própria ideia de fome presente nos escritos de Rubem Alves.

Segundo André Comte-Sponville (2009, p.241):

Como poderíamos escolher nossos desejos ou nossos amores, se só podemos escolher - ainda que entre vários desejos diferentes, entre vários amores diferentes - em função deles? O amor não se comanda e não poderia, em consequência, ser um dever.

Ora, como poderíamos querer que um aluno se apaixonasse por um conteúdo pelo qual ele não sinta desejo? Um conteúdo que ele não ame será um conteúdo dificilmente apreendido. Talvez memorizado, com alguma 
insistência. Entretanto, não aprendido. A proposta de erotização da educação se refere exatamente a uma educação que seja capaz de seduzir, isto é, uma educação "seduzente". E aqui o uso do termo "seduzente" ao invés da palavra "sedutora" se dá porque parece que a primeira opção tem uma ênfase mais positiva que a segunda, aparentando referir-se a algo que tem a capacidade de seduzir por um longo período, ou seja, duradouramente; algo que não é sedutor e se esgota na primeira experienciação e/ou experimentação, mas que continua a seduzir cada vez mais. Uma educação erótica é uma educação em que professores e alunos estejam seduzidos: ambos por aprender e ensinar, ambos por compartilhar. É uma educação em que o espaço de aprendizagem também seduz a quem a ele frequenta. Essa educação não visa necessariamente dar respostas, embora não haja qualquer impedimento para isso, mas seu foco é o despertar do desejo.

Rubem Alves também fala de uma educação como “devoração”. É a educação antropofágica. Aqueles que praticam a antropofagia não o fazem por razões alimentares, diz Alves, mas por amor (2013d, 2014b). Come-se a carne e bebe-se o sangue dos mortos para que eles continuem vivos naqueles que os ingerem. É isso o que fazem as tribos indígenas antropofágicas, porque, uma vez que amam seus mortos, devoram-nos para que ressuscitem de sua morte e permanecem vivos no sangue e na carne daqueles que os devoraram. Em uma educação antropofágica, portanto, devoram-se os conteúdos ensinados para que aquele que ensina e para que os próprios conteúdos estejam sempre dentro de nós, para que permaneçam vivos. "Quando se admira um mestre, o coração dá ordens à inteligência para aprender as coisas que o mestre sabe. Saber o que ele sabe passa a ser uma forma de estar com ele. Aprendo porque amo, aprendo porque admiro" (ALVES, 2002). Não há devoração se não quisermos devorar também a pessoa que é fonte do ensino. É pelo afeto que temos por quem ensina que devoramos. Porque amamos tanto que não queremos que morra jamais. Não é precisamente por isso que devoramos os livros daqueles autores que muito gostamos? Devorar é consumir o máximo possível, é consumir com anseio desmedido. Na educação erótica há devoração, porque há amor, há Eros; e 
devora-se porque existe afeto, há uma relação horizontal entre professores e alunos e perdura uma amizade. Se me apaixono por quem ensina, desejarei aprender tudo o que ele puder ensinar.

Neste aspecto, contudo, há uma importante diferença entre Rubem Alves e Platão: quando falamos em antropofagia falamos em um saber externo, devoramos os ensinamentos que vêm de fora. Ideia oposta à reminiscência, que é um saber interno, rememorado, muitas vezes com um auxílio externo, isto é, com a ajuda de um mestre e através do método dialético que traz à luz o conhecimento já existente em nós. Mas talvez fosse possível pensar em antropofagia e reminiscência como um duplo acontecimento no contexto educacional, com a possibilidade de devoramos os ensinamentos do mestre porque a convivência educacional nos gera a reminiscência de saberes.

De qualquer modo, o amor é a medida da educação. Na antropofagia devora-se porque há amor. Na paiderastia, o amor vem da relação que gera a reminiscência. Assim, se não é possível ter amor, e isto significa sentir-se seduzido, nem tampouco transbordar e doar amor, ou seja, ter a capacidade de seduzir, a educação, então, ou não acontece ou se torna algo desestimulador. "Podem me acusar de ingênuo e romântico: afirmo que a renovação da educação terá que passar pela transformação afetiva dos professores" (ALVES, 2012c, p.138). Portanto, Eros é a essência. Se nos sentimos seduzidos e se o Belo nos é mostrado na relação professor-aluno (e ainda aluno-escola, escola-professor, aluno-conteúdo, etc.), então estamos no caminho certo. Acreditamos que Eros tem uma importância fundamental para a educação contemporânea. Se há muito levamos em alta conta o que dizem outros importantes educadores, como, por exemplo, Paulo Freire com a Pedagogia do Oprimido, que sejam incluídas as sugestões de Rubem Alves no hall de diretrizes para educação, e o ensinamento da Grécia antiga que, em matéria de política e educação, tem muito a nos oferecer.

Os livros de teoria pedagógica que seguimos apresentam métodos para o ensino. Perguntam-se, por isso, como ensinar. Questão esta que gira em torno da busca pela melhor forma de realizar o ensino. Embora estas obras 
nos deem valorosas contribuições, não são nosso melhor norte, já que se tratam de obras escritas em momentos específicos, com base em contextos distintos de grupos particulares. E esquecendo isso, queremos que tais pedagogias valham como método universal para todas as situações e pessoas com as quais vamos nos deparar ao longo da educação. Deveríamos mudar a questão chave e nos perguntar por como despertar o desejo em nossos alunos. A melhor forma de ensiná-los virá em consequência. Se trabalhamos para o despertar do desejo, o melhor método de ensino será aquele que efetive o propósito. Não é necessário sacar as teorias metodológicas pedagógicas fora. Mas que nos lembremos dos ensinamentos da filosofia antiga, que Rubem Alves trabalha com maestria em sua pedagogia do amor. Que o desejo seja o norte e o amor a medida, mesmo dentro do contexto sistêmico da educação mercadológica.

\section{Referências}

ABUjAMrA, Antônio. Provocações. São Paulo, TV Cultura, 03mai.2011. Disponível em <http://tvcultura.com.br/videos/54869_provocacoes-rubemalves.html> Acesso em: 20 de agosto de 2016.

ALVES, Rubem. Aprendo porque amo. Folha de São Paulo [online], São Paulo, 26 nov.2002. Disponível em < http://www1.folha.uol.com.br/folha/sinapse/ult 1063u220.shtml>. Acesso em: 02 de Agosto de 2016.

- Variações sobre o Pražer: Santo Agostinho, Nietzsche, Marx e Babette. São Paulo: Planeta do Brasil, 2011a.

Pensamentos que penso quando não estou pensando. 3.ed. Campinas, SP: Papirus, 2012a.

Por uma educação romântica. 9.ed. Campinas, SP: Papirus, 2012b. . Sete Vezes Rubem. Campinas, SP: Papirus, 2012c.

Estórias de quem gosta de ensinar. 13.ed. Campinas, SP: Papirus, 2013a. . Do universo à Jabuticaba. 2.ed. São Paulo: Planeta do Brasil, 2013b.

Para que os mortos ressuscitem. Correio Popular [online]. Campinas, 07jul.2013. Disponível em <http://correio.rac.com.br/_conteudo/2013/07/ 
colunistas/rubem_alves/77772-para-que-os-mortos-ressucitem.html> Acesso em: 17 de agosto de 2016.

In: OLIVEIRA, Raissa Castro (org.) Ao Professor, com o meu carinho. 3.ed.

Campinas, SP: Verus Editora, 2014a.

- Meditações sobre o educador. Correio Popular [online]. Campinas, 06jul.

2014. Disponível em <http://lojarubemalves.com.br/novosite/wpcontent/uploads/2015/09/Medita\%C3\%A7\%C3\%B5es-sobre-o-educador.

pdf $>$. Acesso em: 17 de agosto de 2016.

BRISSON, Luc; PRADEAU, Jean-François. Vocabulário de Platão. São Paulo: Martins Fontes, 2010.

COMTE-SPONVILlE, A. Pequeno Tratado das Grandes Virtudes. 2.ed. Trad. Eduardo Brandão. São Paulo: Martins Fontes, 2009.

PLATÃO. Fedro. Tradução do grego, apresentação e notas de Maria Cecília Gomes dos Reis, introdução de James H. Nichols Jr. 1.ed. São Paulo: Penguin Classics; Companhia das Letras, 2016.

Lísis. In: Platão Diálogos IV. Tradução, notas e textos complementares de

Edson Bini. Bauru, SP: Edipro, 2009.

. O Banquete. Trad. Carlos Alberto Nunes. 3.ed. Belém: EdUFPA, 2011.

QUEIROZ, Dulce (dir.). Rubem Alves, O Professor de Espantos. Imagens: Cícero

Bezerra e Claudio Adriano. 44 min. TV Câmara, 2013. Disponível em <http://www2.camara.leg.br/camaranoticias/tv/materias/DOCUMENTARIOS/ 434311-RUBEM-ALVES,-O-PROFESSOR-DE-ESPANTOS.html> Acesso em: 20 de agosto de 2016.

REEVE, C. D. C. Eros e a amizade em Platão. In: BENSON, Hugh H. Platão. São Paulo: Artmed, 2011. 